\title{
List of illustrations
}

\section{Figures}

1 St Mary, Buckland St Mary, Somerset, interior looking east through chancel gates opposite page 1

2 Sir Joshua Reynolds and Thomas Jervais, detail from the west window of New College Oxford, 1777-85 (photograph Chris Brooks)

3 Holy Trinity, Tattershall, Lincolnshire, baptism scene from late fifteenth-century window

4 Thomas Willement, number of pieces of work, 1810-69

5 Thomas Willement, number of ecclesiastical and secular commissions, 1810-69 38

6 Thomas Willement, number of commissions for heraldic and figure glass, 1810-69

7 John Toms, St Mary Magdalene, Clatworthy, Somerset, commandment board, 1854

8 John Toms, St Peter, Knowstone, Devon, detail of nave south window, $1856 \quad 58$

9 John Toms, All Saints, Nynehead, Somerset, detail of south aisle window, 185959

10 Illustration from Anna Jameson's Sacred and Legendary Art, first published $1848 \quad 60$

11 John Toms, St Nicholas, Combe St Nicholas, Somerset, detail of tracery light, 1855

12 John Toms, St Mary Magdalene, Clatworthy, Somerset, east window, c. 1860

13 John Toms, St Nicholas, Combe St Nicholas, Somerset, detail of pattern window, 1855

14 Charles Winston, plate 39 from An Inquiry into the Difference of Style Observable in Ancient Glass Paintings, first published 1847

15 John Toms, St Nicholas, Milverton, Somerset, detail of west window, $1850 \quad 68$

16 John Toms, cartoon for canopy, c. 1860 (photograph Chris Brooks) 69

17 John Toms, geographical distribution of windows 71

18 Robert Beer, St Andrew's Chapel, Exwick, Exeter, Devon, 1842

19 Robert Beer, Holy Cross, Cruwys Morchard, Devon, detail of east window, $1847 \quad 82$ 
20 Robert Beer, Oldridge Chapel, Devon, detail of east window, c. 1843

21 Robert Beer, St Thomas of Canterbury, Thorverton, Devon, south aisle east window, 1849

22 J. L. Fulford tracing of medieval stained glass in Exeter Cathedral published in TEDAS in 1847 (with permission of trustees of Chris Brooks)

23 Alfred Beer, the Blessed Virgin Mary, Aylesbeare, Devon, south chancel window, 1850

24 Alfred Beer, St Michael and All Angels, Heavitree, Exeter, Devon, detail of window now the organ loft

25 Alfred Beer, St Mary Magdalene, South Molton, Devon, detail from south aisle east window, c. 1865

26 Alfred Beer, St Mary Magdalene, South Molton, Devon, south aisle east window, c. 1865

27 Alfred Beer, St Martin, Exminster, Devon, south aisle window, c. 1855

28 Alfred Beer, St Michael and All Angels, Poughill, Devon, north aisle east window, 1858

29 Joseph Bell, average price per commission, 1844-55

30 Joseph Bell, the Blessed Virgin Mary, Rattery, Devon, south chapel east window, 1842

31 Detail of window painted by Mary Miles and fired by Joseph Bell, St Mary the Virgin, East Brent, Somerset, 1849 (photograph Peter Cheshire)

32 Joseph Bell, St Michael and All Angels, Buckland Dinham, Somerset, detail from east window, 1849

33 Joseph Bell, turnover, 1844-55

34 Joseph Bell, turnover, trade and non-trade clients, 1844-55

35 Joseph Bell, St John the Baptist, Frenchay, Bristol, west window, c. 1847124

36 Joseph Bell, St Paul, Starcross, Devon, north aisle east window, 1859

37 Joseph Bell, design for the east window of All Saints, Wrington, Somerset, 1860126

38 Joseph Bell, All Saints, Wrington, Somerset, detail of window, c. 1860127

39 Joseph Bell, tracing of medieval glass at East Brent, Somerset, c. 1852129

40 St Mary the Virgin, East Brent, Somerset, detail of window originally made 1450-75, restored by Joseph Bell, c. 1852

41 Michael O'Connor, St Mary the Virgin, Ottery St Mary, Devon, south Lady Chapel window, c. 1850

42 William Warrrington, St Mary the Virgin, Ottery St Mary, Devon, detail from north Lady Chapel window, c. 1850

43 John Hardman and Co., St Mary the Virgin, Ottery St Mary, Devon, detail from north transept east window, 1850 
44 William Wailes, St Andrew, Trent, Dorset, nave window, 1849

45 Joseph Bell, St Michael and All Angels, Buckland Dinham, Somerset, east window, 1849

46 Michael and Arthur O'Connor, St Christopher, Lympsham, Somerset, east window, 1863

47 John Toms and the Beer family, geographical distribution of windows up to 1860168

48 William Wailes, geographical distribution of windows

\section{Colour plates}

between pages 80 and 81

1 St Mary, Buckland St Mary, Somerset, interior looking towards the baptistery

2 Michael O'Connor, St Mary, Buckland St Mary, Somerset, detail from east window, 1857

3 MClayton and Bell, St Mary, Buckland St Mary, Somerset, detail from west window, 1859

4 John Toms, All Saints, Nynehead, Somerset, south aisle west window, 1858

5 Thomas Willement, St Thomas the Martyr, Mamhead, Devon, detail from west window, 1831

6 Joseph Bell, Blessed Virgin Mary, Rattery, Devon, detail from south chapel east window, 1842

7 John Toms, All Saints, Nynehead, Somerset, detail from south aisle window, 1859

8 John Toms, St Giles, Bradford-on-Tone, Somerset, west window, c. 1860

9 Alfred Beer, St Paul, Filleigh, Devon, detail of north aisle east window, c. 1851

10 Alfred Beer, St Michael, Chagford, Devon, detail of east window, 1860

11 Robert Beer, St Mary, Dunsford, Devon, detail of east window, 1845

12 Robert Beer, St Martin and St Mary, Chudleigh, Devon, east window, 1847

13 Alfred Beer, All Saints, Dulverton, Somerset, detail of east window, 1864

14 Joseph Bell, the Blessed Virgin Mary, Rattery, Devon, detail of south chapel south window, 1842

15 Joseph Bell, St Andrew, Trent, Dorset panel, 1850

16 Joseph Bell, the Blessed Virgin Mary, Cheddon Fitzpaine, Somerset, south chancel window, c. 1861

17 Sowton, St Michael and All Angels, Devon, interior looking towards the altar

18 William Warrington and Michael O'Connor, St Mary the Virgin, Ottery St Mary, Devon, adjacent north Lady Chapel windows, c. 1850

19 The stained-glass gallery at the Great Exhibition colour lithograph first published 1852 (V\&A Picture Library)

20 William Wailes, St Andrew, Trent, Dorset, south chancel window, 1842 